\title{
Volumetric flow rate in simulations of microfluidic devices ${ }^{+}$
}

\author{
Kristína Kovalčíková ${ }^{1, *}$, Martin Slavík ${ }^{1, *}$, Katarína Bachratá $^{1}$, Hynek Bachratý${ }^{1}$, and Alžbeta Bohiniková $^{1}$ \\ ${ }^{1}$ Cell-in-fluid Research Group, cell-in-fluid.fri.uniza.sk; Department of Software Technologies; Faculty of Management Science and \\ Informatics, Žilina, Slovakia
}

\begin{abstract}
In this work, we examine the volumetric flow rate of microfluidic devices. The volumetric flow rate is a parameter which is necessary to correctly set up a simulation of a real device and to check the conformity of a simulation and a laboratory experiments [1]. Instead of defining the volumetric rate at the beginning as a simulation parameter, a parameter of external force is set. The proposed hypothesis is that for a fixed set of other parameters (topology, viscosity of the liquid, ...) the volumetric flow rate is linearly dependent on external force in typical ranges of fluid velocity used in our simulations. To confirm this linearity hypothesis and to find numerical limits of this approach, we test several values of the external force parameter. The tests are designed for three different topologies of simulation box and for various haematocrits. The topologies of the microfluidic devices are inspired by existing laboratory experiments [3 - 6]. The linear relationship between the external force and the volumetric flow rate is verified in orders of magnitudes similar to the values obtained from laboratory experiments.
\end{abstract}

\section{Introduction}

The research group Cell in fluid is interested in modelling of elastic objects in fluid flow in solid channels, in order to simulate the flow of the plasma and blood cells in microfluidic devices. The program is developed within open-source software ESPResSo. The model is described in [2]. The numerical simulation of such a device is faster and cheaper to establish, compare with the fabrication of the real microchip.

The long-time goal of the group is to make models of the microfluid devices capturing Circulating Tumour Cells (CTC). At today's stage of the software's development, some calibration calculations are needed, to compare the results of the numeric simulations with results of laboratory experiments. In order to do so, the input parameters influencing the movement of the cells in the blood plasma have to be the same, such as the viscosity of the liquid, the hematocrit, or the volumetric flow rate.

The volumetric flow rate is closely related with the difference of the pressures on the two ends of the device. In the numerical models, this dependence is present as well, and the difference of the pressures is somehow represented by an external fluid force parameter.

We have very often an information about a volumetric flow rate from a laboratory experiment. So we have to find a way how to introduce a known volumetric flow rate into the simulation. That's why we would like to find a way how to define it in the simulation at the beginning, as an input parameter.
It is possible to define the volumetric flow rate directly as an input parameter. The disadvantage of this approach is that we must define the course of the volumetric flow rate across the device, as well. However, it is quite difficult to obtain such an information from laboratory experiment. That's why we look for another option of defining the input flow rate, through the parameter of external fluid force.

The aim of this article is to verify, whether the volumetric flow rate in the simulations of the microfluidic devices is linearly dependent on the parameter of external force, set at the beginning as the simulation parameter. This approach demands only the knowledge of the external force parameter. If it is the case, the wished volumetric flow rate could be obtained by only one iterative simulation.

Authors in [5], p 3296, in sequence "Using a simple syringe to control flow rate" considered different volumetric flow rates in their experiments, and they noticed that "The elastic PDMS device becoming deformed, and inflated, at high pressures. Consequently, the flow rate is not linearly proportional to the applied driving pressure." We do not ignore this feature of the microfluidic devices in our work - our goal is not to show that the volumetric flow rate can be increased infinitely in the laboratory experiments. The aim is to find a way how to define it correctly and rapidly from few calibration simulations.

\footnotetext{
Supported by the Slovak Research and Development Agency under the contract No. APVV-15-0751 and by the Ministry of Education, Science, Research and Sport of the Slovak Republic under the contract No. VEGA 1/0643/17.

*Corresponding authors: kristina.kovalcikova@fri.uniza.sk, martin.slavik@fri.uniza.sk
} 


\section{Methodology}

To confirm the hypotheses of the linear relationship between the volumetric flow rate and the parameter of external force, we tested three different topologies. All of them are inspired by existing laboratory microfluidic devices. Each tested topology consisted of cylindrical or spherical obstacles placed in a rectangular box. The simulation parameter of the external force was set to different values, to verify the linear relationship between the volumetric flow rate and the simulation parameter. In the beginning, we tested the volumetric flow rate in the topologies without the Red Blood Cells (RBC). Afterwards, we ran the simulations without $\mathrm{RBC}$, in order to include more realistic haematocrit in the laboratory experiments.

\subsection{Cylindrical adhesive topology - capturing of CTCs by antibodies-coated obstacles in micro channel}

First tested topology is inspired by works [3] and [4]. Both articles are concerned with a separation of the CTCs. For this purpose, they use a microfluidic device which can capture common CTCs from the patients' blood. The CTC are bigger than ordinary blood cells. While the size of ordinary blood cells ranges from approximately 4 to $18 \mu \mathrm{m}$, CTCs, in contrast, are larger and range from 15 to $25 \mu \mathrm{m}$ in diameter [7]. However, those devices are not designed to isolate the cells by a size-sorting mechanism. Instead, they are using antibodies, spread over the obstacles in microchips. These antibodies capture the CTCs that flow through the channel. The dimensions of the obstacles are designed to stimulate the highest possibility of collisions between the cells and the obstacles.

In [3], the microfluidic devices contain cylindrical obstacles with radius of $50 \mu \mathrm{m}$ placed in equilateral triangular arrangement, with a $50 \mu \mathrm{m}$ distance between obstacles and a $50 \mu \mathrm{m}$ shift after every 3 rows. The device is $100 \mu \mathrm{m}$ deep. The active capture area of the laboratory device was $19 \mathrm{~mm}$ x $51 \mathrm{~mm}$. The volumetric flow rate in the device was about $1-2 \mathrm{ml} / \mathrm{h}$.

In [4], the experiments were made on a GEDI device. It contains cylindrical obstacles with radius of $80 \mu \mathrm{m}$. The gaps between the obstacles are $100 \mu \mathrm{m}$ large, and each subsequent row is shifted by $7 \mu \mathrm{m}$. The device is $100 \mu \mathrm{m}$ deep, $8 \mathrm{~mm}$ wide and $25 \mathrm{~mm}$ long. The volumetric flow rate maintained in the device was of $1 \mathrm{ml} / \mathrm{h}$.

The chosen topology of the simulation channel is presented in the Fig. 1. The radius of the obstacles is $50 \mu \mathrm{m}$, the dimension of the gaps between the obstacles is $50 \mu \mathrm{m}$, and the obstacles are placed in an equilateral triangular array. The simulation channel is $100 \mu \mathrm{m}$ deep, $150 \mu \mathrm{m}$ wide and $260 \mu \mathrm{m}$ long. The volumetric flow rate which should correspond to a $1 \mathrm{ml} / \mathrm{h}$ for a $8 \mathrm{~mm}$ wide device, corresponds to $4,47 \mu \mathrm{m} 3 / \mu \mathrm{s}$.

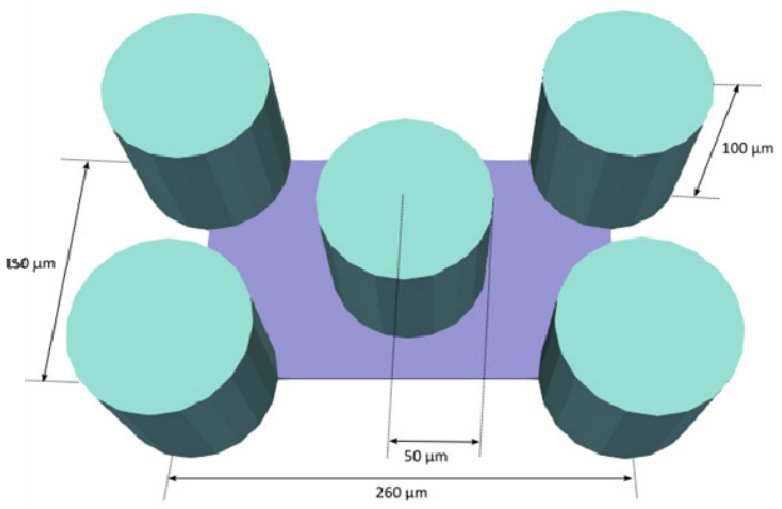

Fig. 1. Description of the simulation channel topology of cylindrical adhesive microfluidic device.

\subsection{Cylindrical sorting topology - sorting of the parasites in the blood according to their size}

The second tested topology is inspired by a device used in the field detection of blood parasites [5]. The aim is to sort the $T$. cyclops parasites from erythrocytes and leucocytes in human blood, using a pattern of obstacles which helps to sort the objects in blood according to their size. The microfluidic device is composed from 3 parts. First part separates the big leucocytes from the smaller erythrocytes and T. cyclops, which have similar dimensions. The second part of the device places the erythrocytes and the parasites close to the boundaries of the device. And the last part of the device keeps the erythrocytes close to the boundaries, while the parasites are placed in the middle stream of the device. The numerical model is inspired by the second part of the microchip.

This second part this microfluidic device consists of cylindrical obstacles, with radius of approximately 10 $\mu \mathrm{m}$. The gap between the obstacles within one row is approximately $20 \mu \mathrm{m}$, and the gap between the rows is approximately $20 \mu \mathrm{m}$ as well. Each row is shifted by one fifth of the distance between the central axes of the obstacles, which means approximately $8 \mu \mathrm{m}$. The depth of the device is $3,5 \mu \mathrm{m}$. The total width of the device is about $2 \mathrm{~mm}$. The volumetric flow rates used in the experiment were in range of 2 to $4 \mu \mathrm{l} / \mathrm{min}$. The device is dimensioned to be used in field, so we considered a haematocrit of a non-diluted blood, which means approximately $40 \%$.

The chosen topology for this device is presented in the Fig.. The radius of the obstacles is $10 \mu \mathrm{m}$. The gap between the obstacles in the row and the distance between the rows is $20 \mu \mathrm{m}$ as well. Each row is shifted by $8 \mu \mathrm{m}$. The depth of the device is $4 \mu \mathrm{m}$. The simulation box has dimensions $200 \times 40 \times 4$ um. The volumetric flow rate which correspond to $2-4 \mu \mathrm{l} / \mathrm{min}$, is about $0.7-1.3 \mu \mathrm{m} 3 / \mu \mathrm{s}$. 


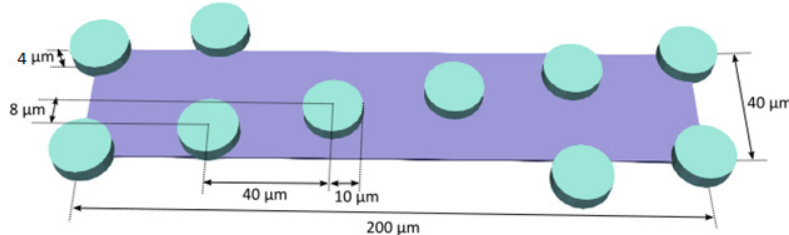

Fig. 2. Dimensions of the simulation channel of the cylindrical sorting topology.

\subsection{Spherical adhesive topology - capturing of the CTCs using antibodies-coated magnetic beads}

The last topology is inspired by work [6] and [8]. Both of them use magnetic beads to construct the microfluidic device. The idea, as well as in [3] and [4], is not to sort the cells according to their size, but to use antibodies which could capture the cells and keep them glued to the obstacle in the device. The advantage of the magnetic beads is that they do not need to be treated with the antibodies inside the channel during or after its construction, as it is a case for devices with cylindrical obstacles. The magnetic beads can be prepared separately, and after the treatment, they are poured into the device, and kept in the right position by an external magnetic field.

The magnetic beads used in [8] have diameter of 4.5 $\mu \mathrm{m}$. In the bottom side of the channel, there is a magnetic pattern which defines the topology of the whole device. Once the beads are poured into the microfluidic channel, the magnetic field is activated, and the beads form chains. Those chains are starting at the specific points defined by the pattern at the bottom of the device. This pattern has a form of an equilateral triangular field. Distance between the chains is $40 \mu \mathrm{m}$. The depth of the device is $50 \mu \mathrm{m}$. It is $0.5 \mathrm{~mm}$ large, and $10 \mathrm{~mm}$ long. The volumetric flow rate in the channel in experiments is few $\mu \mathrm{L} / \mathrm{min}$.

The simulation box inspired by this geometry (Fig. 3) has dimensions of $40 \times 70 \mu \mathrm{m}$. It contains five chains of 12 beads with radius of $2.25 \mu \mathrm{m}$. Four chains are in the corners, and one is in the middle of the box. This way, they form an array of regular equilateral triangular field. The depth of the device is $50 \mu \mathrm{m}$. The volumetric flow rate through this box corresponding to the laboratory experiment is fixed to be $4 \mu \mathrm{m}^{3} / \mu \mathrm{s}$.

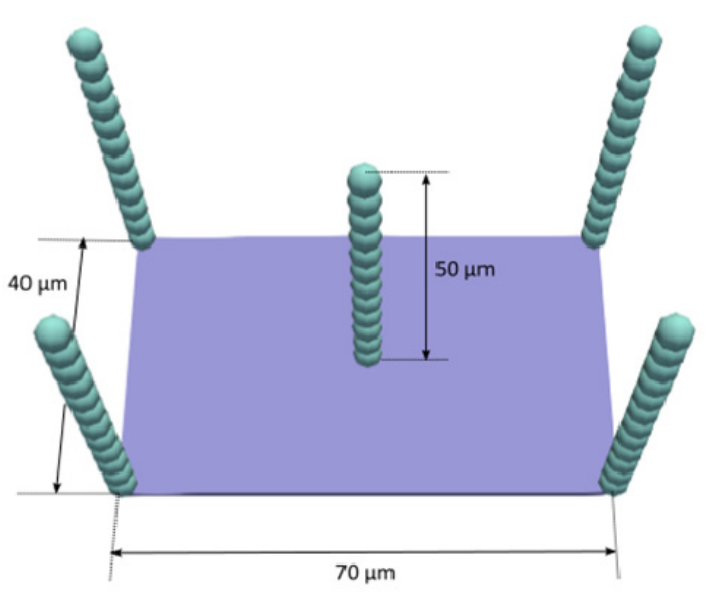

Fig. 3. Dimensions of the simulation channel of the spherical adhesive topology.

\section{Measurement of the volumetric flow rate}

For each topology, the volumetric flow rate was measured in three different positions. In theory, it should have the same value over any cross section of the channel. The possible differences could have origin in numerical imprecision of the simulation.

The three different positions of volumetric flow rate measurement for the cylindrical adhesive topology are shown in the Fig. 4. The evolution of the volumetric flow rate in the three different positions is presented in the Fig. 5 for maximale and minimal examined value of external force parameter (with multiplier of 1 and 500).

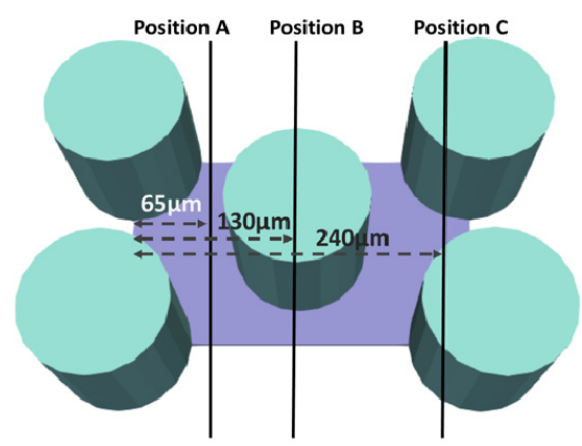

Fig. 4. Dimensions of the simulation channel of the cylindrical sorting topology. 

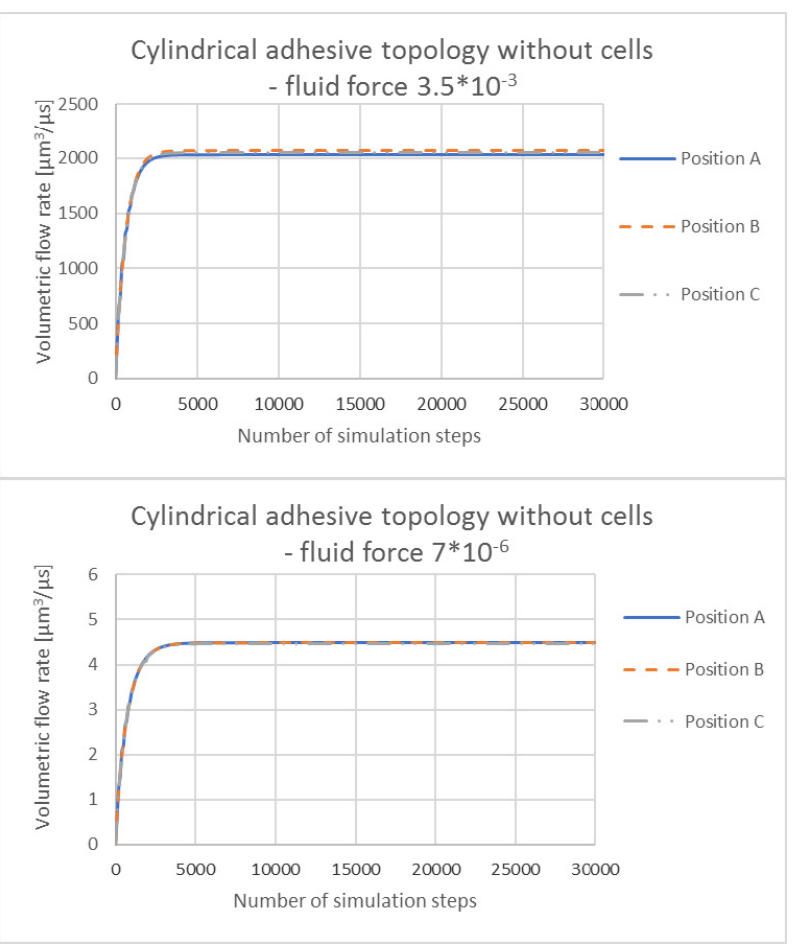

Fig. 5. Cylindrical adhesive topology without cells: comparison between the evolution of the volumetric flow rate measured in three different positions A, B and C. The presented graphs came from the simulation with the smallest and with the highest parameter of external force.

For the cylindrical sorting topology, the volumetric flow rate was measured in three different positions, as well (Fig. 6). The evolution of the volumetric flow rate in the three different positions is presented in the Fig. 7, for the maximal and the minimal examined value of external force parameter - for multipliers 1 and 100 . We can observe that for the multiplier of 100 , the volumetric flow rate is not the same for all positions, but its values differ by $8 \%$. For the multiplier of 50 , its values differ by $3 \%$, and for multiplier of 10 , the measured volumetric flow rate is the same for all the three positions.

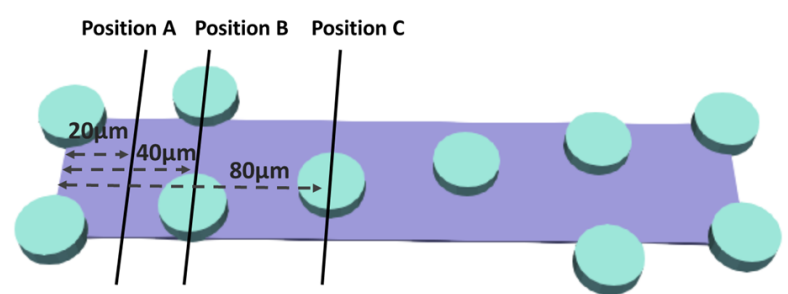

Fig. 6. Three different position of measurement of the volumetric flow rate in the channel with cylindrical sorting topology

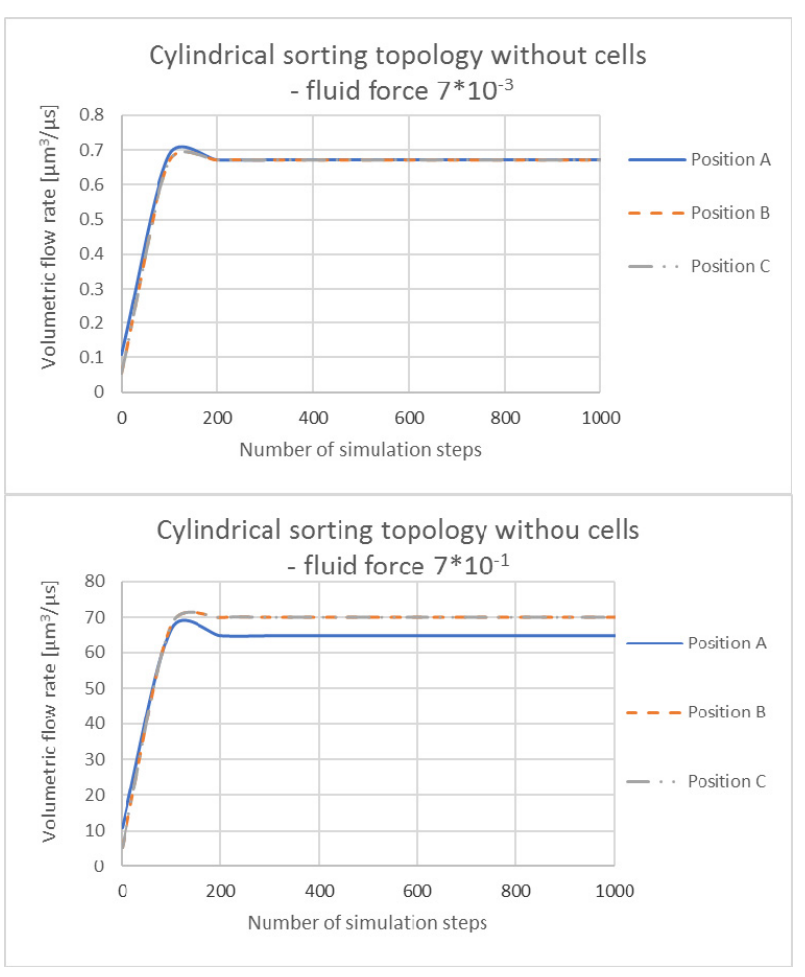

Fig. 7. Cylindrical sorting topology without cells: comparison between the evolution of the volumetric flow rate measured in three different positions $\mathrm{A}, \mathrm{B}$ and $\mathrm{C}$. The presented graphs came from the simulation with the smallest and with the highest parameter of external force.

In the case of spherical adhesive topology, similarly, the volumetric flow rate was measured in three different sections, presented in the Fig. 8. The volumetric flow rates measured in three different positions are presented in Fig. 9. The curves were obtained from simulations with the multiplier 1 and 500. For the multiplier 500, the difference between steady values is $2 \%$.

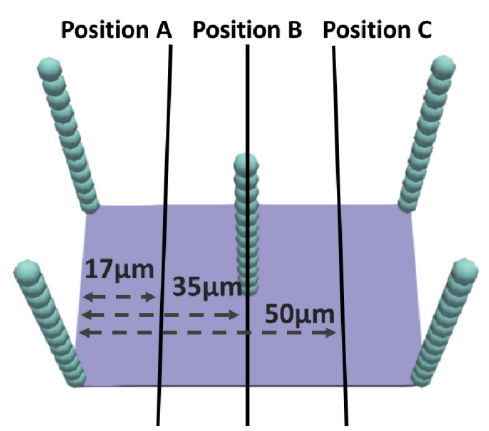

Fig. 8. Three different position of measurement of the volumetric flow rate in the channel with spherical adhesive topology 


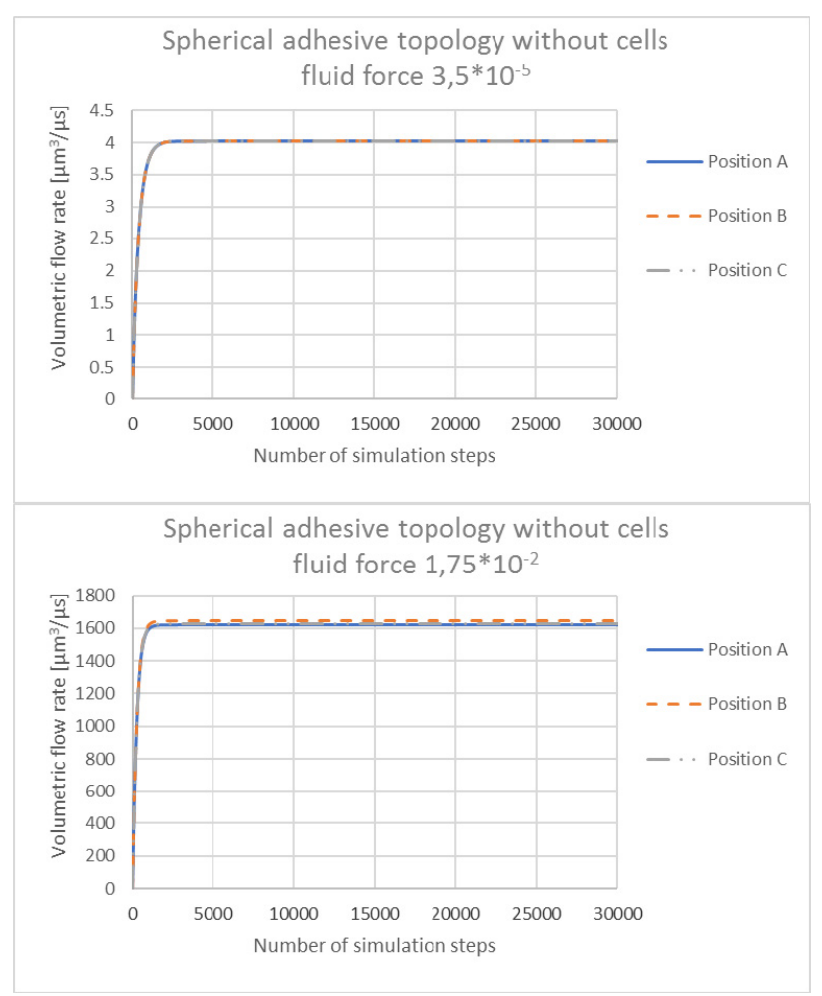

Fig. 9. Spherical adhesive topology without cells: comparison between the evolution of the volumetric flow rate measured in three different positions $\mathrm{A}, \mathrm{B}$ and $\mathrm{C}$. The presented graphs came from the simulation with the smallest and with the highest parameter of external force.

\section{Results}

\subsection{Cylindrical adhesive topology}

The initial value of the external force parameter for the simulation without RBCs was set to 0.000007 , which results in volumetric flow rate of $4,484 \mu \mathrm{m}^{3} / \mu \mathrm{s}$. The value of external force parameter was multiplied afterwards. The results of simulations run with different multipliers are presented in Fig. 10 and Fig. 11.

The initial value of the external force parameter for the simulation without RBCs was set to 0.000007 , which results in volumetric flow rate of $4,484 \mu^{3} / \mu$ s. The value of external force parameter was multiplied afterwards. The results of simulations run with different multipliers are presented in Figure 10 and Figure 11.

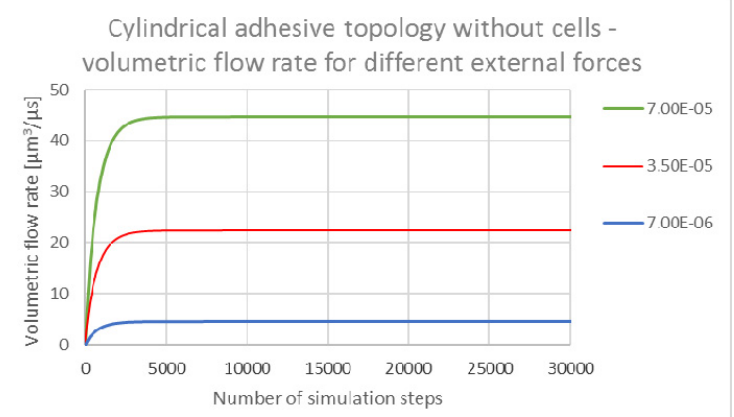

Fig. 10. Example of evolution of the volumetric flow rate during the simulation for three different values of external force for simulations without cells.

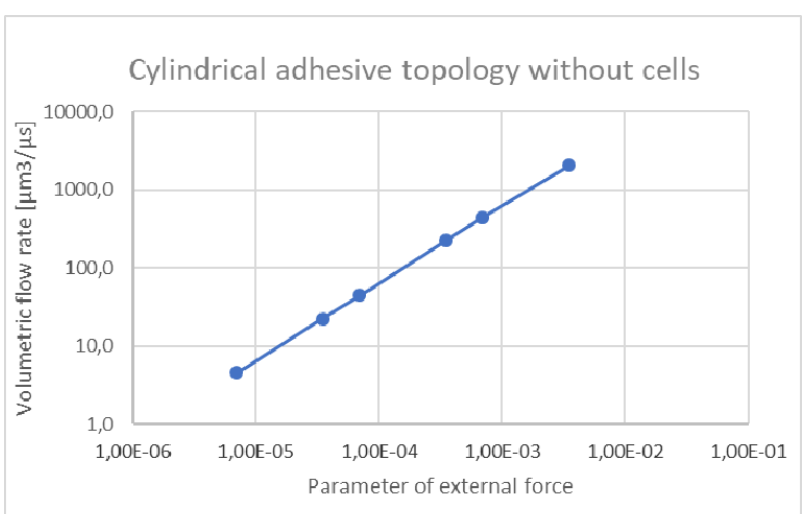

Fig. 11. Relationship between the value of external force parameter and the volumetric flow rate for simulations without cells

For the simulation with cells, we used a hematocrit of approximately $0,5 \%$. Three simulations were run with this level of hematocrit, with three different values of the external force parameter. The simulation with multiplier of 100 did not reached the end, it finished prematurely because of instabilities in the simulation. The obtained values of volumetric flow rates are presented in the Fig. 12.

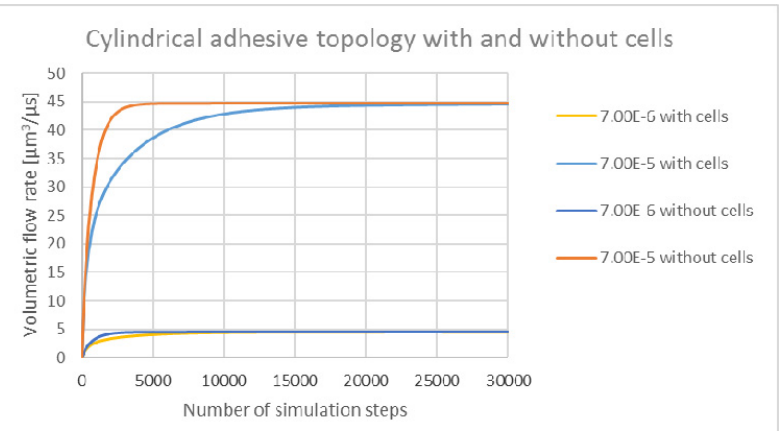

Fig. 12. Comparison between the evolution of the volumetric flow rate for simulations with and without cells.

As we can see in the Table 1, the volumetric flow rate is linearly dependent on the parameter of the external force for the small multipliers. The linearity is more significantly disturbed when the multiplier reaches value of 500 . The percental difference between the obtained and the expected value is about $7.5 \%$.

Another observation we can make is the similarity between values of volumetric flow rates obtained from simulations without RBCs, and the values obtained from simulations with the RBCs. The models with cells get obviously more time to get a stabilized volumetric flow rate, but the final value is similar to the one without cells. More detailed analysis of the similarity between flow rates obtained from simulations with and without cells is presented in the end of this chapter. 
Table 1. Values of volumetric flow rate appropriated to different values of external force parameter.

\begin{tabular}{|c|c|c|c|c|}
\hline & & \multicolumn{3}{|c|}{ without cells } \\
\hline $\begin{array}{l}\text { external } \\
\text { force }\end{array}$ & $\begin{array}{c}\text { multiplier } \\
\text { applied to } \\
\text { the external } \\
\text { force }\end{array}$ & $\begin{array}{l}\text { volumetric } \\
\text { flow rate } \\
{\left[\mu \mathrm{m}^{3} / \mu \mathrm{s}\right]}\end{array}$ & $\begin{array}{c}\text { obtained } \\
\text { multiplier } \\
\text { for } \\
\text { volumetric } \\
\text { flow rate }\end{array}$ & $\begin{array}{c}\text { percentual } \\
\text { difference } \\
\text { between } \\
\text { the two } \\
\text { multipliers }\end{array}$ \\
\hline $7,00 \mathrm{E}-06$ & 1 & 4,5 & 1,0 & $0,0 \%$ \\
\hline $3,50 \mathrm{E}-05$ & 5 & 22,4 & 5,0 & $0,0 \%$ \\
\hline 7,00E-05 & 10 & 44,8 & 10,0 & $0,0 \%$ \\
\hline 3,50 E-04 & 50 & 223,6 & 49,9 & $-0,1 \%$ \\
\hline 7,00 E-04 & 100 & 445,7 & 99,6 & $-0,4 \%$ \\
\hline \multirow[t]{2}{*}{$3,50 \mathrm{E}-03$} & 500 & 2071,4 & 462,7 & $-7,5 \%$ \\
\hline & & \multicolumn{3}{|c|}{ with cells } \\
\hline $\begin{array}{l}\text { external } \\
\text { force }\end{array}$ & $\begin{array}{c}\text { multiplier } \\
\text { applied to } \\
\text { the external } \\
\text { force }\end{array}$ & $\begin{array}{l}\text { volumetric } \\
\text { flow rate } \\
{\left[\mu \mathrm{m}^{3} / \mu \mathrm{s}\right]}\end{array}$ & $\begin{array}{l}\text { obtained } \\
\text { multiplier } \\
\text { for } \\
\text { volumetric } \\
\text { flow rate }\end{array}$ & $\begin{array}{l}\text { percentual } \\
\text { difference } \\
\text { between } \\
\text { the two } \\
\text { multipliers }\end{array}$ \\
\hline 7,00E-06 & 1 & 4,4 & 1,0 & $0,0 \%$ \\
\hline 1,40E-05 & 2 & 8,9 & 2,0 & $0,0 \%$ \\
\hline $7,00 \mathrm{E}-05$ & 10 & 44,5 & 10,0 & $0,3 \%$ \\
\hline
\end{tabular}

\subsection{Cylindrical sorting topology}

The value of external force was set initially to 0,007 , and the obtained volumetric flow rate is $0,67 \mu \mathrm{m} 3 / \mu \mathrm{s}$. The results for different values of the external force parameter settings are presented in the Fig. 13 and Fig. 14. The results from the simulations with cells with hematocrit $20 \%$ are presented in the Fig. 15.

Cylindrical sorting topology without cells -

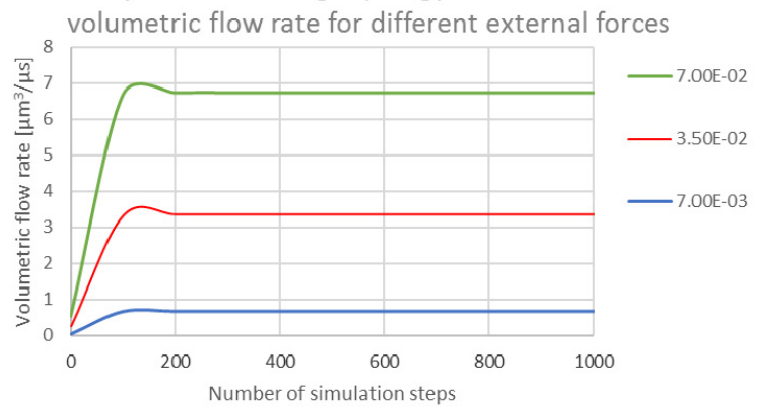

Fig. 13. Example of evolution of the volumetric flow rate during the simulation for three different values of external force for simulations without cells

Cylindrical sorting topology without cells

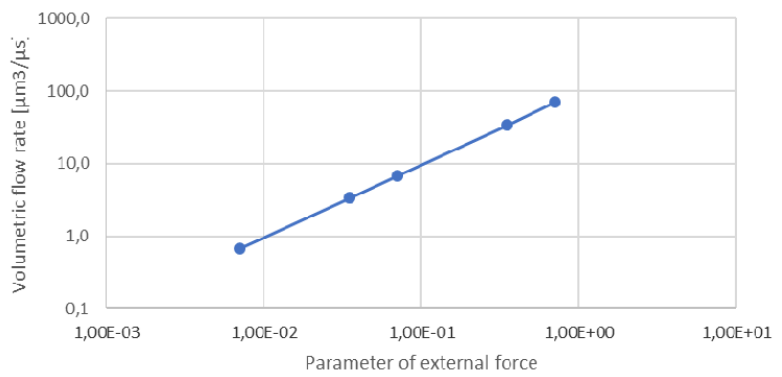

Fig. 14. Relationship between the value of external force parameter and the volumetric flow rate for simulations without cells
Cylindrical sorting topology with and without cells

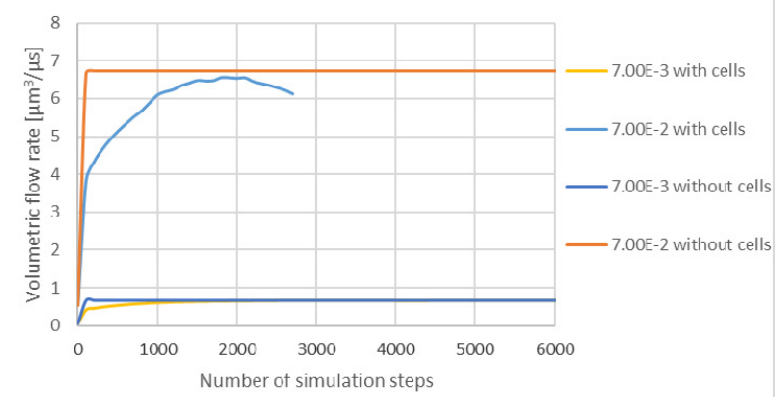

Fig. 15. Comparison between the evolution of the volumetric flow rate for simulations with and without cells.

The observation we make is the very same as for the previous topologies - the volumetric flow rate is linearly dependent on the parameter of external force for the small multipliers (Table 2). The simulations without cells and with a multiplier of 500 finished earlier than expected, due to the numerical instability. However, the expected value of the volumetric flow rate in this simulation corresponds to $1000 \mu \mathrm{l} / \mathrm{min}$, a value 500 times bigger than the value of the real volumetric flow rate in the laboratory experiment. This means that the linearity is preserved for the common range of the volumetric flow rate used in laboratory experiments.

Table 2. Values of volumetric flow rate appropriated to different values of external force parameter. The linearity is slightly perturbed for the big multipliers.

\begin{tabular}{|c|c|c|c|c|}
\hline & & \multicolumn{3}{|c|}{ without cells } \\
\hline $\begin{array}{l}\text { external } \\
\text { force }\end{array}$ & $\begin{array}{c}\text { multiplier } \\
\text { applied to } \\
\text { the } \\
\text { external } \\
\text { force }\end{array}$ & $\begin{array}{c}\text { volumetric } \\
\text { flow rate } \\
{\left[\mu \mathrm{m}^{3} / \mu \mathrm{s}\right]}\end{array}$ & $\begin{array}{l}\text { obtained } \\
\text { multiplier } \\
\text { for } \\
\text { volumetric } \\
\text { flow rate }\end{array}$ & $\begin{array}{c}\text { percentual } \\
\text { difference } \\
\text { between the } \\
\text { two } \\
\text { multipliers }\end{array}$ \\
\hline $7,00 \mathrm{E}-03$ & 1 & 0,7 & 1,0 & $0,0 \%$ \\
\hline $3,50 \mathrm{E}-02$ & 5 & 3,4 & 5,0 & $0,1 \%$ \\
\hline $7,00 \mathrm{E}-02$ & 10 & 6,7 & 10,0 & $0,2 \%$ \\
\hline $3,50 \mathrm{E}-01$ & 50 & 34,1 & 50,7 & $1,4 \%$ \\
\hline \multirow[t]{2}{*}{$7,00 \mathrm{E}-01$} & 100 & 70,1 & 104,3 & $4,3 \%$ \\
\hline & & \multicolumn{3}{|c|}{ with cells } \\
\hline $\begin{array}{l}\text { external } \\
\text { force }\end{array}$ & $\begin{array}{c}\text { multiplier } \\
\text { applied to } \\
\text { the } \\
\text { external } \\
\text { force }\end{array}$ & $\begin{array}{c}\text { volumetric } \\
\text { flow rate } \\
{\left[\mu \mathrm{m}^{3} / \mu \mathrm{s}\right]}\end{array}$ & $\begin{array}{c}\text { obtained } \\
\text { multiplier } \\
\text { for } \\
\text { volumetric } \\
\text { flow rate }\end{array}$ & $\begin{array}{c}\text { percentual } \\
\text { difference } \\
\text { between the } \\
\text { two } \\
\text { multipliers }\end{array}$ \\
\hline $7,00 \mathrm{E}-03$ & 1 & 0,6 & 1 & $0 \%$ \\
\hline $1,40 \mathrm{E}-02$ & 2 & 1,3 & 2,1 & $3 \%$ \\
\hline
\end{tabular}

\subsection{Spherical adhesive topology}

The initial value of the external force parameter was set to 0.000035 , which results in volumetric flow rate of $4.02 \mu \mathrm{m}^{3} / \mu \mathrm{s}$. The results obtained by modifying this parameter are presented in the Fig. 16 and Fig. 17 for without cells simulations, and in the Fig. 18 for simulations with cells. The hematocrit used for simulations with cells is $15 \%$. 


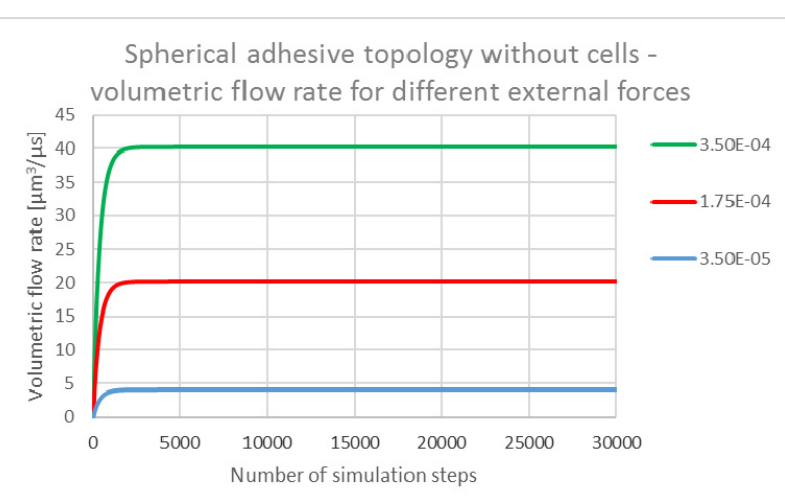

Fig. 16. Example of evolution of the volumetric flow rate during the simulation for three different values of external force for simulations without cells

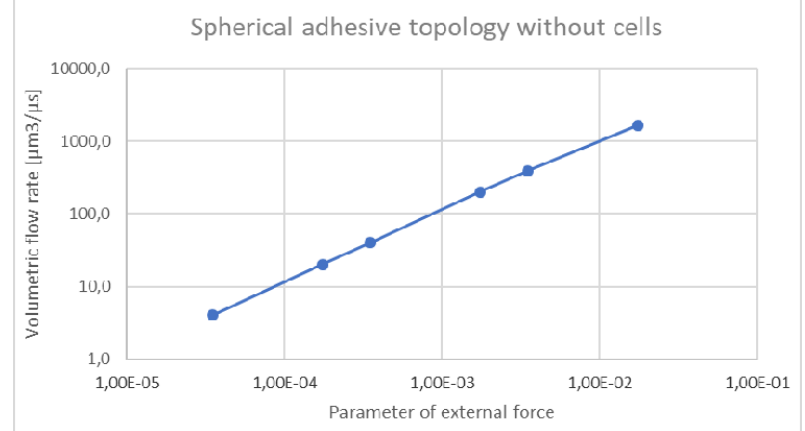

Fig. 17. Relationship between the value of external force parameter and the volumetric flow rate for simulations without cells.

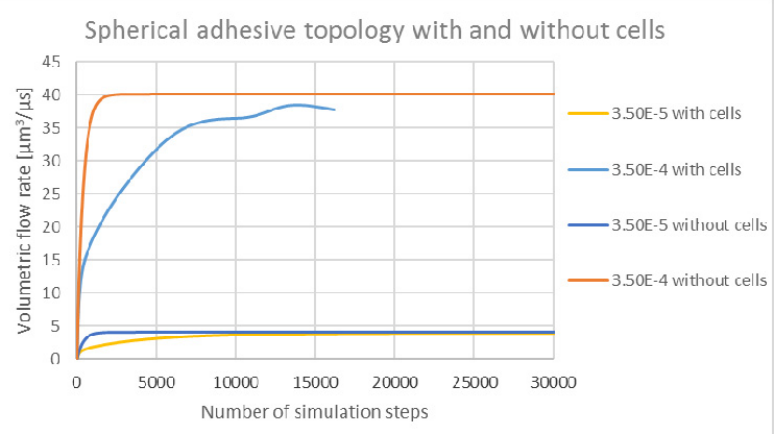

Fig. 18. Comparison between the evolution of the volumetric flow rate for simulations with and without cells.

Table 3. Values of volumetric flow rate appropriated to different values of external force parameter. The linearity is slightly perturbed for the big multipliers.

\begin{tabular}{|c|c|c|c|c|}
\hline \multirow[b]{2}{*}{$\begin{array}{l}\text { external } \\
\text { force }\end{array}$} & \multirow[b]{2}{*}{$\begin{array}{l}\text { multiplier } \\
\text { applied to } \\
\text { the external } \\
\text { force }\end{array}$} & \multicolumn{3}{|c|}{ without cells } \\
\hline & & $\begin{array}{c}\text { volumetric } \\
\text { flow rate } \\
{\left[\mu \mathrm{m}^{3} / \mu \mathrm{s}\right]}\end{array}$ & $\begin{array}{l}\text { obtained } \\
\text { multiplier for } \\
\text { volumetric } \\
\text { flow rate }\end{array}$ & $\begin{array}{c}\text { percentual } \\
\text { difference } \\
\text { between the } \\
\text { two } \\
\text { multipliers }\end{array}$ \\
\hline $3,50 \mathrm{E}-05$ & 1 & 4,0 & 1,0 & $0,0 \%$ \\
\hline $1,75 \mathrm{E}-04$ & 5 & 20,1 & 5,0 & $0,0 \%$ \\
\hline $3,50 \mathrm{E}-04$ & 10 & 40,2 & 10,0 & $0,0 \%$ \\
\hline $1,75 \mathrm{E}-03$ & 50 & 199,6 & 49,6 & $-0,7 \%$ \\
\hline $3,50 \mathrm{E}-03$ & 100 & 391,8 & 97,4 & $-2,6 \%$ \\
\hline \multirow[t]{2}{*}{$1,75 \mathrm{E}-02$} & 500 & 1644,6 & 409,1 & $-18,2 \%$ \\
\hline & & \multicolumn{3}{|c|}{ with cells } \\
\hline $\begin{array}{l}\text { external } \\
\text { force }\end{array}$ & $\begin{array}{l}\text { multiplier } \\
\text { applied to } \\
\text { the external } \\
\text { force }\end{array}$ & $\begin{array}{c}\text { volumetric } \\
\text { flow rate } \\
{\left[\mu \mathrm{m}^{3} / \mu \mathrm{s}\right]}\end{array}$ & $\begin{array}{c}\text { obtained } \\
\text { multiplier for } \\
\text { volumetric } \\
\text { flow rate }\end{array}$ & $\begin{array}{c}\text { percentual } \\
\text { difference } \\
\text { between the } \\
\text { two } \\
\text { multipliers }\end{array}$ \\
\hline $3,50 \mathrm{E}-05$ & 1 & 4,0 & 1,0 & $0,0 \%$ \\
\hline $7,00 \mathrm{E}-05$ & 2 & 7,83 & 2,0 & $-1,1 \%$ \\
\hline
\end{tabular}

The linear relationship between the volumetric flow rate and the external force parameter is partially verified (Table 3). The linearity is valid for multipliers smaller than 100. For the multiplier of 500, the difference between the obtained and the expected volumetric flow rate is about $18 \%$.

The value of external force was set initially to 0,007 , and the obtained

\subsection{Comparison of volumetric flow rate for simulations with and without cells}

The values are comparable for simulations with and without the cells, especially for simulations with a low hematocrit. The simulation with a high hematocrit shows that it influences the volumetric flow rate in a significant way, even for values close to the laboratory conditions. The comparison between the volumetric flow rates obtained from simulations with and without the cells are presented in the Table 4.

Table 4. Volumetric flow rate variation due to presence of the

\begin{tabular}{|c|c|c|c|c|}
\hline \multirow{2}{*}{ Type of topology } & \multirow{2}{*}{$\begin{array}{c}\text { External } \\
\text { force }\end{array}$} & \multicolumn{2}{|c|}{$\begin{array}{l}\text { Volumetric flow } \\
\text { rate }[\mu \mathrm{m} 3 / \mu \mathrm{s}]\end{array}$} & \multirow{2}{*}{$\begin{array}{l}\text { Percentuel } \\
\text { difference for } \\
\text { vomuletric flow } \\
\text { rate with and } \\
\text { without cells }\end{array}$} \\
\hline & & $\begin{array}{l}\text { without } \\
\text { cells }\end{array}$ & $\begin{array}{l}\text { with } \\
\text { cells }\end{array}$ & \\
\hline \multirow{2}{*}{$\begin{array}{c}\text { Cylindrical } \\
\text { adhesive topology }\end{array}$} & $7,00 \mathrm{E}-06$ & 4,48 & 4,44 & $-1 \%$ \\
\hline & $7,00 \mathrm{E}-05$ & 44,76 & 44,52 & $-1 \%$ \\
\hline $\begin{array}{l}\text { Cylindrical sorting } \\
\text { topology }\end{array}$ & 7,00E-03 & 0,67 & 0,63 & $-6 \%$ \\
\hline $\begin{array}{c}\text { Spherical adhesive } \\
\text { topology }\end{array}$ & $3,50 \mathrm{E}-05$ & 4,02 & 3,96 & $-2 \%$ \\
\hline
\end{tabular}

\section{Conclusions}

In our study, we have tested the linear dependence of the volumetric flow rate on the parameter of the external fluid force. For this purpose, we have tested the hypothesis on three different topologies inspired by existing laboratory experiments. The results show that for the range of values commonly used in the laboratory, the hypothesis is valid. For volumetric flow rates which exceed the laboratory conditions by a factor of hundreds, the linearity is not certain.

Another observation is that for high values of the external force parameter, simulations are less stable, particularly the simulations with cells.

An interesting observation can be done about the time necessary for the simulation to get a stabilized volumetric flow rate. For simulations without cells, this time is 2 to 3 times shorter than for the simulations with the same topology and with cells inside the liquid.

\section{References}

[1] I. Cimrák, M. Gusenbauer, T. Schrefl, Computers and Mathematics with Applications, 64(3), 278-288 (2012)

[2] I. Cimrák, M. Gusenbauer, I. Jančigová, Computer Physics Communications, 185, 900-907 (2014) 
[3] S. Nagrath, L.V. Sequist et al., Nature, 450, 12351239 (2007)

[4] J.P. Gleghorn et al., Lab Chip, 10, 27-29 (2010)

[5] S.H. Holm, J.P. Beech, M.P. Barret, J.O. Tegenfeldt, Anal. Methods, 8, 3291-3300 (2016)

[6] D. Horák, Biomed Mater Res Part A, 101A, 23-32 (2013)

[7] S. Zheng, H. Lin, J. Liu, M. Balic, R. Datar, R. Cote, Y. Tai, Journal of Chromatography A, 1162, 154-161 (2007)

[8] A. E. Saliba et al., PNAS, 107, 14524-14529 (2010) 